\title{
Emoção e argumentação: um estudo das cartas de romeiros endereçadas ao Padre Cícero
}

\author{
Edmar Peixoto de Lima (UERN)* \\ https://orcid.org/0000-0001-8827-1136 \\ Márcia Pereira da Silva Franca (UERN)** \\ https://orcid.org/0000-0002-3507-3571 \\ Maria José Fernandes da Silva Araújo (SEEC/RN)***
https://orcid.org/0000-0002-3969-0729 \\ Talita Araújo Costa (UERN)**** \\ https://orcid.org/0000-0002-2596-133X
}

\begin{abstract}
Resumo:
Este artigo objetiva analisar os aspectos argumentativos presentes em cartas de romeiros endereçadas ao Padre Cícero, observando como os escritores expressam emoções no discurso e que aspectos extralinguísticos e linguísticos são utilizados para construir essas impressões emocionais nas cartas. A pesquisa se fundamenta em Amossy (2018), Bakhtin (2016) e Braga (2007). 0 corpus se constitui de cinco (05) cartas e, com base nesses textos, verificamos que os produtores acionam as emoções (pathos) no discurso (logos), considerando a imagem (ethos) revelada de si, estando esses três princípios (ethos, logos e pathos) articulados na empreitada persuasiva. Os resultados evidenciam que a imagem do locutor alcança uma dimensão valorativa graças aos aspectos interacionais envoltos nos contextos sociais, culturais e enunciativos, os quais incluem a esfera cotidiana e familiar como
\end{abstract}

Professora Adjunta do Departamento de Letras Vernáculas (DLV), da Universidade do Estado do Rio Grande do Norte (UERN) e do Programa de Pós-Graduação em Letras da Universidade do Estado do Rio Grande do Norte (PPGL/UERN). Doutora em Linguística Aplicada pela Universidade Estadual do Ceará (UECE). Mestra em Letras pela Universidade do Estado do Rio Grande do Norte (UERN). Lattes: http://lattes.cnpq.br/3705801164982732.E-mail: professoraedmar@gmail.com

* Professora de Língua Portuguesa da Secretaria da Educação Básica do Ceará (SEDUC). Doutoranda e mestra em Letras pela Universidade do Estado do Rio Grande do Norte (UERN). Lattes: http://lattes.cnpq. br/2624924237203967. E-mail: marciafranca60@yahoo.com.br

*** Professora de Língua Portuguesa da Secretaria de Estado da Educação do Rio Grande do Norte (SEEC/RN). Doutoranda em Letras pela Universidade do Estado do Rio Grande do Norte (UERN). Mestra em Letras pela Universidade Federal do Rio Grande do Norte (UFRN). Lattes: http://lattes.cnpq.br/6905504227139621. E-mail: masefernandes@hotmail.com

${ }^{* * * *}$ Professora de Língua Portuguesa da Rede Municipal de Ensino do Município de Itaú/RN. Doutoranda e mestra em Letras pela Universidade do Estado do Rio Grande do Norte (UERN). Lattes: http://lattes.cnpq. br/3801204011097253. E-mail: talitinha.jp@hotmail.com 
mediadora e reguladora das emoções. As expressões empregadas viabilizam inúmeros efeitos patêmicos e estão materializadas por meio de advérbios de intensidade, pronomes possessivos, substantivos, verbos imperativos, entre outros. Esses recursos, presentes na saudação, na motivação para a escrita e na despedida, caracterizam a força argumentativa evidenciada na mobilização das emoções, que funcionam como parte integrante do discurso, na tentativa de influenciar o outro, considerando, sobretudo, as subjetividades do auditório.

Palavras-chave: Argumentação; Pathos; Gênero carta de romeiro.

\section{Abstract:}

\section{Emotion and argumentation: a study of letters from pilgrims addressed to Father Cícero}

This article aims to analyze the argumentative aspects present in letters from pilgrims addressed to Father Cícero, observing how the writers express emotions in their speech writing and what extralinguistic and linguistic aspects are used to make such emotional impressions in the letters. The research is based on Amossy (2018), Bakhtin (2016) and Braga (2007). The corpus consists of five (05) letters and, based on those texts, we noticed the authors trigger the emotions (pathos) in their speech (logos), regarding the image (ethos) revealed of themselves, being these three principles (ethos, logos and pathos) articulated in a persuasive engagement. The results shows that the image of the speaker achieves a value dimension thanks to the interactional aspects involved in the social, cultural and enunciative contexts, which include the daily and family sphere as a mediator and regulator of emotions. The words they used to express themselves enable countless pathogenic effects and they are materialized through degree adverbs, possessive pronouns and possessive adjectives, nouns, imperative verbs, among others. These resources, present in their greetings, in their motivation for writing and when saying goodbye, feature the argumentative power evidenced in the mobilization of emotions, which work as the whole part of the discourse, in an attempt to influence the reader, regarding, above all, the subjectivities of the audience.

Keywords: Argumentation; Pathos; Genre pilgrim letter.

\section{Introdução}

O uso da palavra constitui uma ação argumentativa por natureza, especialmente se considerarmos que todo dizer é produzido com a finalidade de atingir um objetivo perante o interlocutor. Essa ação se realiza nas práticas sociais por meio da linguagem verbal, oral ou escrita. Imersos nessas reflexões que aparecem frequentemente em estudos da área da argumentação, tanto nos que se ocupam de trabalhos de cunho mais linguístico e descritivo, quanto naqueles que apresentam características discursivas, observamos que o nível de argumentatividade é bastante variável nos diferentes textos. 
Ora nos deparamos com textos mais argumentativos, ora com textos menos, e essa argumentatividade depende, entre outros aspectos, dos gêneros do discurso em que se inscrevem os textos, cujos elementos interferem diretamente na sua construção.

Esta pesquisa elege como foco analítico a carta de romeiro, especificamente um corpus constituído por cinco (05) cartas endereçadas ao líder religioso Padre Cícero do Juazeiro do Norte, no ano de 2001. Por meio dessas cartas, investigamos o modo como os produtores revelam/expressam as emoções e os efeitos provocados por elas no interlocutor $^{1}$. Seguindo uma perspectiva de análise argumentativa do discurso que considera os quadros genéricos em que estão inseridos os textos (AMOSSY, 2018) e tomando como norte o nosso objetivo de pesquisa, buscamos respostas para os seguintes questionamentos: i) de que maneira os produtores das cartas mobilizam os efeitos emocionais no discurso? ii) que aspectos extralinguísticos e linguísticos influem na construção argumentativa das emoções e dos sentidos dos textos?

Para respondermos às questões suscitadas, respaldamo-nos teoricamente em uma concepção discursiva, interacional e dialógica da língua. Com relação aos gêneros do discurso, utilizamos os estudos bakhtinianos ${ }^{2}$, especialmente Bakhtin (2016); no

1 Neste artigo, empregamos mais de uma forma linguística para nos referirmos aos participantes do discurso, tendo em vista que articulamos perspectivas teóricas distintas, razão pela qual não padronizamos esses usos. Desse modo, utilizamos, indistintamente, locutor, falante, orador ou sujeito, em relação àquele que profere o discurso; assim como interlocutor, auditório ou alocutário, para aquele a quem o discurso é direcionado.

2 Denominamos estudos bakhtinianos as pesquisas realizadas por Mikhail Bakhtin e os demais integrantes do chamado Círculo de Bakhtin (Pável Medviédev, Valentin Volochínov, entre outros). tocante à análise argumentativa, elegemos teorias aristotélicas (ARISTÓTELES, 2000, 2005) e a Argumentação no Discurso proposta por Amosssy (2018).

Sendo esta pesquisa embasada em uma visão interacional e dialógica da língua, os textos analisados são compreendidos como entidades completas de sentido, propriedade esta que subjaz à consideração dos conceitos de texto, discurso e gênero como noções correlacionadas consubstancialmente.

Do ponto de vista metodológico, elegemos as cartas seguindo alguns conceitos de Aristóteles (pathos, ethos e logos) e a perspectiva de análise argumentativa do discurso de Amossy (2018), de forma articulada. Em seguida, destacamos alguns aspectos interacionais, sócio-históricos e discursivos de Bakhtin (2016). De acordo com esse autor, a análise dos gêneros deve centrar-se nos elementos da interação, nos aspectos sociais e contextuais e, por último, mas não menos importante, na materialidade textual.

A carta de romeiro apresenta em sua constituição três partes: abertura, corpo e encerramento (NASCIMENTO, 2018). Tomando por base as leituras anteriormente realizadas das cartas que integram o corpus desta pesquisa, pressupomos que as escolhas lexicais realizadas pelos produtores para a construção dos segmentos saudação, motivação para a escrita e despedida, localizados, principalmente, na abertura e no encerramento das cartas, apresentam uma força argumentativa que pode ser justificada por meio dos elementos interacionais e dialógicos que compõem as situações sociais identificadas nos textos.

A pesquisa apresenta uma configuração que, a nosso ver, possibilita contribuições para os estudos da argumentação, especialmente porque conjuga os elementos argumentativos com os discursivos ao pro- 
por uma análise que se realiza por meio de instrumentos retóricos e interacionais/ dialógicos. Ademais, destacamos que os estudos centrados nas questões que envolvem o pathos, ou mais precisamente sobre as emoções no discurso como estratégia de argumentação, ainda necessitam de muitas investigações, de modo que esta pesquisa poderá viabilizar possíveis caminhos para novas perspectivas investigativas, que abordem também outros gêneros do discurso.

\section{Questões teóricas e}

\section{metodológicas aplicadas ao gênero do discurso carta de romeiros}

Bakhtin (2016) define os gêneros do discurso como formas de enunciados que apresentam uma certa estabilidade. De acordo com o autor, a análise dos gêneros deve centrarse nas diferentes formas de interação, por meio das quais são evidenciados os aspectos sociais e históricos dos sujeitos, assim como o contexto de produção dos enunciados e, a partir disso, a materialidade textual. Os aspectos teórico-metodológicos que caracterizam a concepção de gêneros do discurso defendida por Bakhtin (2016) condizem com os objetivos a que nos propomos nesta investigação, o que justifica a escolha dessa teoria para a análise do corpus em estudo as cartas de romeiros.

Seguindo esse mesmo viés, Branco (2012, p. 21) lembra que "a relativa instabilidade de um gênero estaria relacionada à sua historicidade passada (memória do passado)". A autora destaca que os gêneros se apresentam como um reflexo de usos realizados em um dado momento e que os enunciados vão se constituindo pelo acúmulo de lembranças. Podemos, nesse sentido, citar a carta de romeiro como um gênero que emerge no contexto em que a fé em um padre se pauta no discurso alicerçado na crença, pois cada carta sugere questões que suscitam respostas imediatas, baseadas em histórias contadas e repercutidas durante os anos. Nas cartas, é possível visualizar costumes, práticas, economia e cultura de um povo.

De acordo com Volóchinov (2017, p. 232), “[em] cada palavra de um enunciado compreendido, acrescentamos como que uma camada de nossas palavras responsivas. Quanto maior for o seu número, quanto mais essenciais elas forem, tanto mais profunda e essencial será a compreensão". Esse autor opõe-se à ideia monológica do texto, à predominância de uma única voz e compreende a diversidade de vozes existentes no interior de um texto, defendendo o teor polifônico que o caracteriza. Desse modo, o enunciado pressupõe um ato de comunicação social e, nessa interação, o locutor não espera que seu interlocutor seja passivo, mas que ao compreender o enunciado, adote um comportamento responsivo, que concorde ou refute. $\mathrm{O}$ autor discute o agir sobre o outro, o influenciar a busca pela adesão e, nesse sentido, afirma que o enunciado é único, pois uma vez constituído no momento de interação, não há possibilidade de repeti-lo. Ademais, para o autor, o enunciado é resultado de construções proferidas em outros momentos, por isso resultante de uma memória discursiva.

As cartas produzidas pelos romeiros pertencem a situações particulares, no que se refere a pedidos, agradecimentos e aconselhamentos, mas se assemelham no seu contexto de produção, pois "cada dor é uma dor, cada esperança é uma esperança" (RAMOS, 2011, p. 11). 0 romeiro do Padre Cícero escreve ao santo quando por algum motivo não consegue peregrinar a Juazeiro do Norte, no Ceará e, por isso, en- 
contra nas cartas, enviadas por um portador, a oportunidade de se fazer presente na romaria.

Identificadas como um gênero primário (BAKHTIN, 2016) e pertencendo à esfera cotidiana, as cartas, pelo seu caráter simples, típico de conversação, representa um gênero mais popular, menos clássico e que reflete a história, a cultura e a crença de um povo. $\mathrm{Na}$ carta de romeiro, consideramos não somente a estrutura do gênero, mas também o papel do sujeito no processo de produção textual e a presença das escolhas lexicais que compõem as proposições na construção de sentidos. Essas cartas refletem situações cotidianas, reais e concretas. São situações vivenciadas que se materializam no gênero ou em forma de pedido ou de agradecimento àquele em quem se acredita poder minimizar ou sanar as dores promovidas pelas circunstâncias, pelas mazelas mundanas. De acordo com Nascimento (2018, p. 44), “a carta se presta a diferentes fins".

No que se refere à estrutura, a carta de romeiro segue os padrões das cartas clássicas ou pessoais, apresentando os seguintes elementos: o vocativo, por meio do qual há o contato e a interação com o destinatário; o corpo da carta, onde se encontra o assunto; e o encerramento, que inclui a despedida, seguido da assinatura do remetente. Ao afirmarmos que as cartas seguem os "padrões clássicos", não estamos atribuindo ao gênero um caráter estanque, mesmo porque ele apresenta mudanças na sua estrutura. Referimo-nos à presença dos elementos supramencionados que, em alguma medida, podem ser identificados, conferindo a esse gênero uma certa estabilidade. De acordo com Nascimento (2018, p. 43), “[h]á variações que podem ser interpretadas como decorrência natural da especificidade da interação verbal a qual deve estabelecer certas condições para efetivar as produções discursivas dos gêneros".

0 remetente da carta de romeiro considera-se afilhado do padre Cícero e o considera um verdadeiro santo e padrinho, por isso, o conteúdo muitas vezes revela um caráter sigiloso e causa a impressão de que o padre receberá em mãos o documento. Embora breves, as cartas retratam uma fé ampla e compartilhada por milhares de romeiros que acreditam no atendimento a pedidos feitos por homens comuns, mas protegidos pelo sacerdote.

Segundo Braga (2007, p. 302), "Padre Cícero era visto como aquele que acolhia a população pobre em geral, seja o doente, o 'louco', o criminoso disposto a se arrepender, o beato e mesmo os sem (literalmente) nada". Os fiéis, em sua maioria, eram constituídos de um público que direta ou indiretamente se via representado por aqueles que o padre atendia. 0 assunto que origina as cartas direcionadas ao sacerdote reflete a gratidão pelos feitos e o desejo por algo que varia da saúde a um bem material, até mesmo votos de felicidade e casamento compõem os ditos das cartas. Segundo Ramos (2011, p. 10), "[p]edidos, versos ou orações não são decretos, regimentos ou bulas papais, são discursos sem vírgulas que têm o fôlego da esperança. São vozes arranhadas pela vida, são mãos de corpo rústico que embalam o sertão e desenham as letras de umas 'mal traçadas linhas'”.

A carta de romeiro é a representação concreta da multiplicidade de vozes que circundam o gênero. Ainda hoje se acredita que o Padre Cícero não morreu, talvez isso explique a representação das cartas enviadas ao sacerdote com pedidos por escrito, já que os romeiros creem na possibilidade de recebimento e, consequentemente, da leitura por parte do padre e do atendimento 
àquilo que compõe o plano composicional e o propósito comunicativo do gênero.

Ancorados na fé, os romeiros acreditam no "encantamento do padre" e não na sua morte, permanecendo, desse modo, o mistério que circunda a crença em um homem simples que até pouco tempo nem o reconhecimento da igreja católica tinha, mas move milhares de pessoas de todos os estados do Brasil, seja com a presença física ou por meio de cartas que fidelizam ainda mais a confiança que se tem no "padim".

\section{A argumentação como elemento constitutivo do discurso e o papel das escolhas lexicais}

As relações humanas se materializam com base na dimensão dialógica da linguagem, uma vez que os interlocutores assumem diversos papéis no ato comunicativo e recorrem, para isso, aos diversos recursos linguísticos com o propósito de agir sobre o outro de algum modo. Por essa razão, compreendemos que argumentar é uma “ação que tende sempre a modificar um estado preexistente" (PERELMAN \& OLBRECHTS -TYTECA, 2005, p. 61).

Partindo desse entendimento, aludimos aos preceitos defendidos por Amossy (2018), que sugere uma teoria de análise da argumentação em uma perspectiva discursiva, visto que a autora compreende a ação de argumentar como uma dimensão constitutiva do discurso, quer dizer, que atravessa o discurso. Ancorada nos estudos da clássica e da nova retórica, articulando-os à Análise do Discurso de orientação francesa, essa proposta da autora considera a argumentação como parte integrante da análise discursiva.

Sob essa perspectiva, Amossy (2018, p. 47) toma a argumentação como
Os meios verbais que uma instância de locução utiliza para agir sobre seus alocutários, tentando fazê-los aderir a uma tese, modificar ou reforçar as representações e as opiniões que ela lhes oferece, ou simplesmente orientar suas maneiras de ver, ou de suscitar um questionamento sobre um dado problema.

A argumentação é concebida por meio da utilização dos recursos que a linguagem disponibiliza para as construções discursivas. As falas, como também as relações estabelecidas entre os falantes, em determinadas situações comunicativas, evidenciam considerações a respeito do lugar social, das instâncias institucionais, das opiniões e das teses defendidas pelos integrantes das trocas verbais. Há argumentação quando um ponto de vista é manifestado ou quando há uma tentativa de fazer um determinado público aderir a uma tese. Destarte, todo discurso supõe o ato de fazer funcionar a linguagem. Isso significa que não há discurso sem enunciação, sem dialogismo, sem a interação e a comunicação dos sujeitos participantes da comunicação.

Amossy (2018, p. 11) explica que a teoria da argumentação no discurso “[explora] não somente a visada, mas também a dimensão argumentativa da fala". Essa teoria possibilita análises de diversos corpora, o que significa que essa perspectiva autoriza a análise de inúmeros gêneros do discurso, considerando tanto a dimensão quanto a visada argumentativa. Desse modo, por estender as análises argumentativas a um corpus múltiplo, vimos espaço para desenvolvermos as nossas reflexões sobre o papel dos recursos linguísticos na construção das emoções como estratégias argumentativas em cartas de romeiros ao Padre Cícero.

É por meio do uso da linguagem em contextos distintos que surge a manifestação 
de uma dimensão argumentativa, inerente a muitos discursos. Essa dimensão equivale a uma apresentação elementar, por um enunciador, de um ponto de vista sobre uma determinada questão. Quer dizer, os gêneros discursivos, que em sua construção composicional apresentam essa dimensão argumentativa, visam orientar os modos de ver e de pensar do auditório. Citamos, como exemplo, a reportagem, que é um tipo de texto que tem como finalidade informar, descrever algo, ou algum acontecimento, e também pode exercer função formadora de opinião.

A visada argumentativa particulariza alguns tipos de discursos, ou seja, em algumas dessas manifestações, os aspectos que envolvem o caráter da argumentação são materializados nitidamente. Nessa extensão, os falantes apresentam, explicitamente, um constante esforço para fazer com que o auditório aceite as ideias defendidas. Há, portanto, nessas manifestações, o intuito de influenciar o alocutário de alguma forma. Como exemplo de gênero do discurso que possui essa extensão argumentativa, podemos citar o discurso eleitoral, já que quando um candidato produz e direciona o discurso a um público-alvo, ele o constrói com o uso de vocábulos que julga apropriados a contribuírem no processo de convencimento dos seus eleitores ou possíveis votantes. Com essa construção, o orador pretende realizar uma empreitada persuasiva direcionada aos ouvintes, com o propósito, possivelmente, de convencê-los sobre as propostas governamentais apresentadas.

A Análise Argumentativa no Discurso autoriza estudos de textos múltiplos, com finalidades distintas, e oferece instrumentos que possibilitem reconhecer as diversas negociações de que necessitam os textos no processo de argumentar. Por essa razão, es- ses preceitos servem de base para as nossas reflexões em relação ao manejo do léxico no corpus selecionado para esta pesquisa, a saber, o gênero do discurso carta de romeiro. Cremos que o léxico acionado pelos produtores no processo de escrita das cartas manifesta carga argumentativa, pois a palavra tem uma força que se exerce nas trocas verbais, quer dizer, o léxico acionado em uma determinada estrutura discursiva denuncia muito dos propósitos aspirados pelo produtor, por ser ele um elemento influenciador no arranjo argumentativo do texto.

O processo das escolhas lexicais não é feito aleatoriamente, visto que cada palavra possui uma carga semântica e, consequentemente, um peso argumentativo. Nesse seguimento, cada indivíduo aciona as palavras que constituem o seu vocabulário para alcançarem as suas pretensões, e é nesse viés que almejamos observar quais escolhas lexicais foram realizadas pelos romeiros, nas cartas direcionadas ao Padre Cícero, e de que maneira esses acionamentos mobilizam as paixões como estratégia de argumentação. Dessa forma, por meio dos fundamentos evidenciados por Amossy (2018), encontramos subsídio teórico-analítico para nos aprofundarmos nas análises das cartas que compõem o corpus selecionado para esta pesquisa.

\section{As emoções na arquitetura argumentativa do texto}

A argumentação convoca inúmeros recursos linguísticos e extralinguísticos para se fazer presente nas práticas de linguagem, entre eles, destacamos os componentes retóricos, que nas palavras de Aristóteles (2005), são fundamentais na arte de persuadir: o ethos, o pathos e o logos. 0 primeiro diz respeito à imagem que o locutor revela de si mesmo, 
seu caráter moral, construído por meio do discurso; o segundo, que consiste no ponto central das discussões propostas nesta pesquisa, corresponde às emoções ou paixões provocadas pelo orador no auditório e encontra-se imbricado ao logos, que se refere aos elementos racionais, lógicos, àquilo que é considerado verdadeiro e também está presente na teia discursiva. Tendo em vista o objetivo desta pesquisa, que consiste em investigarmos o modo como os produtores das cartas de romeiros mobilizam as paixões no auditório, daremos ênfase a esse aspecto, na presente seção teórica, mas aludindo, também, ao ethos e ao logos.

Quando se refere ao pathos, Aristóteles (2005, p. 160), afirma que "as emoções são as causas que fazem alterar os seres humanos e introduzem mudanças nos seus juízos, na medida em que elas comportam dor e prazer [...]". De acordo com a visão aristotélica, é por meio do raciocínio produzido com seus interlocutores que o orador gerencia as paixões, razão pela qual logos e pathos se interligam, em diferentes níveis e combinações do discurso. Para Aristóteles (2000, p. $\mathrm{XL})$, “[...] as paixões são as respostas às representações que os outros concebem de nós, são representações em segundo grau". Elas constroem a imagem que concebemos do outro, na nossa mente, levando em conta também o que esse ser representa para nós. Com base nessas reflexões, o autor defende existir, na Retórica, um jogo de imagens que refletem entre si não apenas a imagem que idealizamos do outro, mas também aquilo que ele enxerga relativamente a nós. São catorze as paixões na Retórica aristotélica, a saber: "cólera, calma, temor, segurança (confiança, audácia), inveja, impudência, amor, ódio, vergonha, emulação, compaixão, favor (obsequiosidade), indignação e desprezo" (ARISTÓTELES, 2000, p. XLI).
Na concepção aristotélica, o pathos abriga enorme relevância no processo de construção persuasiva do discurso, porque age sobre o auditório, persuadindo-o, sendo o logos (o próprio discurso) o meio pelo qual o orador busca despertar tais emoções. Observando por esse ângulo, o logos representa o elo entre esses participantes do discurso (RODRIGUES-ALVES; RADI, 2016). Ao conduzir o auditório a agir de determinada forma, o pathos mobilizado no discurso pelo orador configura-se em uma imagem que comove por diferentes motivações e/ou estados emotivos.

Considerando essas discussões e os conceitos de ethos, pathos e logos, tratados no início da presente seção, entendemos como necessária as considerações desses três princípios aristotélicos, de forma articulada e equilibrada, para compreendermos as emoções como argumentos acionados na empreitada de persuadir o auditório. Apesar de colocarmos como foco desta investigação os efeitos patêmicos suscitados nas cartas de romeiros, entendemos, com base nas discussões elencadas anteriormente, que o discurso (logos) estará sempre munido de ethos e pathos, na construção retórica dos argumentos, não sendo possível, portanto, abordar esses princípios de forma isolada.

Nascimento (2015, p. 50), ao discutir sobre a relação entre pathos, ethos e lógica, na retórica aristotélica, chama-nos a atenção para a importância atribuída ao uso do ethos na estrutura do discurso, destacando que "[...] a persuasão ou a coação acontecem quando somos superiores, senhores ou amigos (a superioridade de que nos fala Aristóteles é a superioridade da virtude)". O autor nos lembra, desse modo, a importância que o filósofo atribui ao conhecimento das emoções, para, assim, o orador alcançar o objetivo de persuadir o auditório, pois é o conhe- 
cimento que permitirá ao orador munir-se dos argumentos de que necessita.

Assim como é importante o orador inteirar-se sobre as paixões, também é preciso que ele conheça o auditório que deseja influenciar. Nesse ponto, consideramos relevantes as reflexões empreendidas por Fiorin (2018, p. 74) acerca do pensamento bakhtiniano sobre o auditório:

Cada auditório é particular, porque cada um tem seus conhecimentos, crenças, valores e emoções diversos. No entanto, há um auditório não especializado, que poderíamos com Bakhtin denominar auditório médio, que é aquele auditório que acredita nos valores dominantes num dado tempo numa determinada formação social. 0 orador sempre escolhe e articula seus argumentos em função de um ponto de vista sobre o auditório.

Associando o pensamento desse autor aos contextos interacionais e enunciativos em que são produzidas as cartas de romeiro analisadas neste trabalho, observamos que há paridades no modo como podemos conceber o conceito de auditório das referidas cartas. Nelas, o Padre Cícero é o interlocutor por excelência, a julgarmos pelas escolhas lexicais presentes, mas ao levarmos em conta, nesta situação de comunicação, os aspectos sociais, culturais e temporais, compreendemos que o auditório das cartas está representado por algo muito mais amplo que, a princípio, parece-nos difícil caracterizar, mas evidencia no discurso, por meio dos efeitos emocionais produzidos, seus valores, posições ideológicas, convicções ou crenças.

Seguindo também um viés discursivo, Amossy (2018) convoca à cena questões relevantes sobre a forma como as emoções são construídas no discurso, com vistas à persuasão. A autora nos adverte sobre o cuidado que devemos ter para não confundir o pathos com as emoções demonstradas pelo falante - cuja afetividade não apresenta tanta relevância nesse contexto - nem com o sentimento conferido a alguém, veiculado em um texto. 0 pathos incide sobre o auditório, mas ele corresponde, conforme também prega Aristóteles, na emotividade suscitada no outro, construída discursivamente, seja de forma explícita, quando podemos identificá-la nitidamente na materialidade textual, seja de uma maneira implícita, cuja identificação exige do analista o conhecimento sobre a cultura, modos de vida e conduta próprias de determinados contextos comunicacionais.

Atribuindo essas conceituações às cartas de romeiro que compõem o corpus desta pesquisa, julgamos necessárias as considerações tanto de elementos argumentativos visíveis quanto dos aspectos situacionais impressos nas cartas, os quais abrigam as relações sociais e dialógicas entre os devotos e o Padre Cícero, como também os lugares sociais que eles ocupam e os papéis que exercem na comunicação. Isso justifica a razão pela qual propomos uma análise que contemple os aspectos interacionais, enunciativos e linguísticos, decorrente, segundo Rojo (2005, p. 198), da síntese proposta por Bakhtin, que relaciona "os elementos da situação de comunicação, as práticas de linguagem e [os] gêneros do discurso".

Essa proposta de análise, especialmente no que se refere ao estilo da linguagem utilizada, coaduna com o debate empreendido por Amossy (2018, p. 213, grifos nossos), quando a pesquisadora questiona sobre os modos como os aspectos emocionais são postos no discurso e, para chegar a uma resposta, ela remete a questão à pragmática linguística. Vejamos:

[...] o pathos está ligado à inscrição da afetividade na linguagem tanto quanto às tópicas que fundamentam o discurso. Isso nos re- 
mete à questão de saber como a afetividade pode ser colocada no discurso. Essa questão é hoje tratada pelas ciências da linguagem e, em particular, pela pragmática linguística, que, após ter estudado a enunciação da subjetividade na linguagem (Kerbrat-Orecchioni, 1980), debruça-se sobre a emoção expressa linguisticamente. [...] Em síntese, o emissor verbaliza uma emoção (sinceramente sentida ou não) por marcadores que o receptor precisa decodificar para sentir seus efeitos emocionais (Kerbrat-Orecchioni, 2000: 59). Esses marcadores podem ser identificados graças às categorias semânticas do afetivo e do axiológico.

A autora acrescenta que os aspectos emocionais - o pathos - produzidos discursivamente inscrevem-se na organização sintática do texto, englobando, desde a ordem em que estão postos os elementos linguísticos, até recursos alusivos às exclamações e às interjeições. Esses mecanismos atuam diretamente no auditório, despertando, em alguma medida, uma emoção. Outro modo de imprimir a afetividade no discurso consiste no emprego de "marcas estilísticas (o ritmo, a ênfase, as repetições)". A linguista considera uma tarefa difícil diferenciar as marcas que inscrevem afetividade das que simplesmente externam emoção (AMOSSY, 2018, p. 214).

Analisamos as cartas de romeiro orientando-nos por esses instrumentais teóricos da argumentação, considerando também as formas de interação, que incluem aspectos sociais e históricos dos sujeitos; contexto de produção dos enunciados; recursos linguísticos. É importante reiterar que Amossy (2018) aponta os princípios para a análise argumentativa do discurso, propondo uma abordagem que se realiza tanto por meio do acionamento dos recursos disponíveis na língua - os lexemas, por exemplo -, como também pela consideração dos participantes da interação, das relações dialógicas es- tabelecidas com outros discursos, além dos quadros enunciativos inerentes ao gênero, que é visto pela autora como uma entidade definidora e reguladora dos papéis sociais, condição indispensável ao funcionamento argumentativo do discurso.

\section{Efeitos emocionais possiveis}

Conforme abordamos na segunda seção deste trabalho, uma análise dos gêneros que se orienta pela concepção de Bakhtin (2016) deve considerar as formas de interação que evidenciam os aspectos sócio-históricos dos sujeitos no processo da comunicação. Assim sendo, ao refletirmos sobre o modo como os devotos/oradores mobilizam as emoções, necessário se fez elencarmos o contexto de produção dos enunciados, o qual envolve as situações sociais em que estão inseridos os interlocutores dos textos. Essas situações identificadas nas cartas dos romeiros abrigam relações sociais que são estruturadas de acordo com os lugares ocupados pelos parceiros e com os objetivos da comunicação.

Ao analisarmos as relações dialógicas estabelecidas entre eles, nas cartas, consideramos o papel social desempenhado pelo Padre Cícero, um líder religioso, um patriarca, um profeta, um protetor, um guia ao caminho da salvação (BRAGA, 2007) e, acima de tudo, o Padrinho (ou Padim, como era e é frequentemente chamado pelos devotos) cujo carisma é apresentado de forma bastante acentuada nas cartas. Esses discursos constituem, desse modo, o cenário de uma relação afetiva e carismática entrelaçada à devoção ao Padre Cícero, resultando em uma expressividade que instaura os efeitos emocionais no auditório por meio da materialidade textual, que atribui aos textos um estilo peculiar. Com base nessas discussões, passemos à análise dos textos. 


\section{Carta 1}

Meu Padrinho Cicero hoje estou lhe escrevendo esta carta para lhe pedi um milagre. Meu Padrinho Cicero vou lhe pedi com tanta fé e amor.

É que o meu filho vive no mundo da perdição, usando drogas. Eu quero que o senho ajude ele a sair dessa vida, que ele voltasse a ser um rapaz bom, onesto que ajudava nós. Porisso meu Padrinho Cícero, ajude. o ilumine o caminho dele, e proteja ele de tudo e de todos, que ele abuse as drogas, meu Padrinho ele não quer trabalhar ponha no coração dele que ele tem que trabalhar ajude meu padrinho Cicero, para que ele não cometa nenhuma besteira e não brigue mais os meninos.

Aqui finalizo com tanta fé e esperança que um dia meu filho se livre dessas drogas:

Ass: M. S. S. S.

0 parágrafo inicial da carta 1 evidencia intensificação da fé e do amor que o orador julga usufruir ao textualizar o pedido ao Padre Cícero. 0 enunciado "com tanta fé e amor" sugere um efeito de expressão patêmica que tem por finalidade sensibilizar o interlocutor ao ponto de ele atender a sua súplica, considerando, para isso, a noção de fé como mola propulsora primeira, mas que acompanhado do amor se torna ainda mais poderosa. A construção do texto, sob o nosso ponto de vista, possibilita a inferência de o texto ser capaz de conduzir o Padre Cícero a um estado favorável à aceitação da tese por meio do pedido revestido de dor e preocupação, o que comprovamos com os ditos do próprio orador ao explicitar que a realização do pedido se trata de um "milagre".

A autora introduz o texto com a saudação - afetuosa - ao padre, o que é característica do gênero carta, encerrando o parágrafo com a mobilização de elementos linguísticos capazes de provocar emoções profun- das no leitor. A escrevente repete por duas vezes o vocativo "Meu Padrinho Cícero", na introdução do texto, demonstrando estar esperançosa em relação ao êxito que obterá com o seu pedido de ajuda e, ao mesmo tempo, parecendo aflita, angustiada e ansiosa por socorro, mediante a situação que está vivenciando com o filho.

As escolhas lexicais realizadas pela produtora do texto na construção enfatizada "Meu Padrinho Cícero" apresentam cargas semânticas relacionadas à ideia de posse, materializada no uso do pronome possessivo "meu" e, ao recorrer ao grau diminutivo "padrinho", a autora nos instiga a refletir sobre a relação de intimidade que ela estabelece com o padre, ou seja, se ele é seu padrinho, na condição de afilhada, ela necessita de sua proteção.

Convém destacar que a relação concretizada pelos elementos linguísticos "padrinho" e pela inferência "afilhada" desconstrói a ideia de padre apenas como autoridade religiosa. O uso da expressão "padrinho" configura ao texto, além da relação de intimidade já mencionada, a ideia de parentesco, uma vez que, segundo as crenças sociais, os padrinhos de uma criança assumem a posição dos pais na ausência desses. 0 contexto situacional em que essa relação é estabelecida socialmente revela muito do que se acredita compartilhar, pois o batizado, cerimônia religiosa em que se institui o batismo, segundo os preceitos católicos, é o sacramento que transforma a pessoa pagã em filha de Deus. 0 ritual funciona como uma espécie de contrato em que os padrinhos assumem diante de Deus, perante os pais e a comunidade, o compromisso de ajudar na educação do afilhado. É nesse contexto que o uso de "padrinho" é mencionado pela produtora do texto. Consideramos, portanto, que a escolha por esses léxicos é, também, uma forma 
de influenciar o interlocutor pelo fato de instigarem determinados tipos de emoções.

A repetição da expressão vocativa ressaltada anteriormente evidencia ao interlocutor diversos sentimentos que a solicitante demonstra no momento que escreve a carta e, embora esteja triste por conta da realidade que enfrenta com o filho, ela tem fé e revela manter a esperança de que o quadro dele possa ser revertido, considerando a intervenção do "padim". Nesse sentido, o segundo parágrafo, que corresponde ao corpo do texto no qual deve constar as informações que norteiam o discurso, é constituído pelas razões que motivam o pedido e fundamentam o desespero que é revelado pelo ethos do orador por meio da súplica do milagre.

Contudo, há a imbricação de argumentos racionais e emotivos na justificativa do pedido e da consequente possível resposta. Enquanto no enunciado "meu filho vive no mundo da perdição", a ideia de "perdido no mundo" revela a concepção de alguém arruinado ou cheio de vícios. Nós identificamos na carta os sentimentos de dor, de desespero e, possivelmente de expectativa no Padre Cícero, como a última esperança de regaste e de salvação do filho; para isso, o orador recorre como embasamento a informação "usando drogas". Esse último enunciado demonstra o motivo racional pelo qual a mãe recorre ao padre, suplica o milagre e, em seguida, retoma com a descrição detalhada do que se espera do sacerdote. Para reforçar o pedido por meio de argumentos considerados sólidos e concretos, a mãe recorre à descrição das qualidades que o filho tinha antes de se envolver no mundo das drogas. Possivelmente, a mãe alude a esta estratégia de explicitação dos aspectos positivos do filho com a finalidade de fornecer credibilidade à tese de que aquele que precisa do milagre também é merecedor da dádiva.

A fundamentação da argumentação na carta 1 vale-se do desejo de uma mãe que roga pela recuperação do filho e acredita que o Padre Cícero seria capaz de resgatá -lo não somente do mundo das drogas, mas com as qualidades que outrora o caracterizam. 0 apelo ao pathos é mobilizado a fim de atribuir um caráter persuasivo ao discurso. Assim, a dor, a súplica e a crença no Padre Cícero são reveladas nos enunciados em que o orador pede, relata, descreve tanto a situação em que o possível merecedor do milagre vive, como as qualidades que lhe eram comuns antes das drogas. 0 logos se manifesta nas razões, neste caso, textualizadas pelas expressões "o uso de drogas" e a "falta de interesse para o trabalho", que o orador expõe como justificativa para o pedido.

Dessa forma, o apelo aos efeitos patêmicos mobilizados pelo orador possibilita a comoção, a nosso ver, por meio da aflição de uma mãe que sofre, intercede pelo seu filho e busca influenciar o auditório por meio das emoções suscitadas, na tentativa de conduzi-lo a aceitar à tese apresentada, materializada no clamor de uma mãe atormentada.

Como exige o gênero, há um parágrafo de conclusão e, nele, o orador intensifica ainda mais as emoções que a circundam, a fé e a esperança, e retoma os dizeres do parágrafo inicial “com tanta fé e esperança”, só que ao invés de amor, o orador aciona a expressão esperança, demonstrando possuir confiança de que o seu clamor será ouvido.

Dando prosseguimento, passaremos para a análise da segunda carta selecionada.

\section{Carta 2}

Potengi ce 060701

Meu padre cicero

Meu padre cicero peço ao senhor que abencoi essa familia iluminando cada pas- 
so, dando saúde, paz, alegria, felicidade e tudo de bom.

Meu padre cicero peço também que o senhor afaste tudo aquilo de mal que venha a encostar nesta casa.

Sei que sem o esforço da busca é impossivel a vitória e que a esperança e a ultima que morre mais com certeza sei de uma coisa muito importante que com fé no senhor vamos alcançar o nosso futuro e sabe a resposta do nosso presente que foi a fé o amor e o carinho que temos por o senhor.

Por isso em nome de toda essa familia peço que o senhor nos guarde e nos livre de tudo quanto for mal e nos conceda sempre com esse carinho que temos [...] tenho e sempre iremos de ter

Obrigado por tudo oque o senhor fez, faz e fará por essa família...Amém

A segunda carta revela um ethos menos sofrido, mais alegre, otimista e confiante no Padre Cícero. A autora pede ao padre bênçãos e proteção para ela e toda a sua família, não enfatizando nenhum problema específico, como o que constatamos na primeira carta. É notório que nessa súplica há a presença de uma enorme gratidão materializada pelos milagres já alcançados no passado, no presente e que também serão permitidos pela entidade religiosa no futuro. 0 texto atende às características do gênero ao mencionar expressões que revelam saudação, texto introdutório, corpo e despedida.

0 orador demonstra estar ou sentir-se muito próximo ao sacerdote, pois além da presença do pronome possessivo "meu" no vocativo, a expressão "meu Padre Cícero" é repetida no parágrafo inicial. 0 uso desse pronome na construção vocativa apresentada denota um forte vínculo, uma estreiteza na ligação de fé entre a intercessora e o padre, e transmite ao leitor a ideia de que essa ação de escrever/solicitar algo à referência religiosa é uma coisa já natural, habitual para a escrevente e, igualmente, a sua crença em relação à escuta dos seus anseios.

Diferentemente da primeira carta, o orador da segunda inicia pedindo bênçãos para sua família e essa solicitação não é direcionada a um único sujeito, mas a um grupo. A descrição das bênçãos contempla "saúde, paz, alegria, felicidade e tudo de bom". Observemos, ainda, que o orador usa palavras de sentidos muito próximos como: "alegria, felicidade e tudo de bom". O objetivo do orador, a nosso ver, nesse excerto, é mobilizar o sujeito interpretante por meio da emoção e da felicidade. 0 texto configura-se em um apelo aos efeitos patêmicos materializados em expressões que influenciam o interlocutor, na perspectiva do orador, a sensibilidade necessária para o atendimento à prece, ou seja, a adesão à tese apresentada.

Aparentemente, trata-se de alguém grato pelas bênçãos alcançadas por intermédio do padre e que reforça a certeza de pertencer ao grupo dos que serão sempre abençoados pelo sacerdote, o que não deixa de ser mais uma estratégia de persuasão para a garantia do acompanhamento constante. Esse sentimento de gratidão pode ser comprovado no parágrafo de conclusão, quando o locutor se despede, afirmando: "Obrigado por tudo que o senhor fez, faz e fará por essa família ... Amém". A locutora utiliza o verbo "fazer" em diferentes tempos verbais, intensificando o que acredita que continuará acontecendo em relação aos seus pedidos e à situação da sua família. 0 processo das escolhas lexicais não é realizado aleatoriamente no fechamento da carta, pois cada manifestação do verbo escolhido revela um peso semântico significativo e, consequentemente, argumentativo ao discurso. 
O orador, no corpo da carta, afirma saber que é necessário esforço para que se alcance a vitória e a importância da esperança, contudo enfatiza que "com fé no senhor [Padre Cícero] vamos alcançar o nosso futuro", ou seja, mesmo considerando sua participação no construto da felicidade que tanto almeja, é no padre que se tem a maior credibilidade, o que garante maior confiabilidade no santo e no futuro que ele permitirá que vivam.

Assim sendo, apelar ao pathos possibilita a comoção do possível auditório por meio da segurança do que continuará existindo, no seio da família: a felicidade, a alegria e a esperança de que os familiares nunca serão desamparados pelo "padrinho", elementos que sustentam a argumentação na carta.

Seguimos para a análise da terceira carta selecionada.

\section{Carta 3}

Meu Padrinho Cicero não vou poder lhi visitar este ano. Estou com o coração muito partido, mais meu Padrinho eu lhi pesso que mim ajude hora muito dificil estou passando na minha vida.

Pois eu troquei o amor verdadeiro por um amor que eu sei que não existe. Deixei o amor de minha mãe por um amor falso que ama outra pessoa queria que umas páginas da minha vida voltace ao passado mais que sei que isto não vai acontecer eu lhi pesso que mim ajude faça com que está pessoa goste um pouco de mim mim abençõe meu padrinho e minha familia ass: M. F. S.

Na terceira Carta, o orador inicia afirmando não poder visitar o Padre Cícero naquele ano e, por essa razão, demonstra tristeza por não o fazer. É possível confirmar tal comprovação pelo dizer: "estou com o coração muito partido" e o orador intensifica, ainda, que o coração não está somente partido, mas "muito" partido. Percebemos nessa intensificação o caráter de valor atribuído à dimensão da dor, uma vez que esse advérbio atribui um teor de tristeza profunda materializada pela expressão "coração partido". A presença dessa metáfora revela a gravidade da dor expressa pelo orador, posto que aciona na cognição do auditório os significados possíveis que um coração partido mobiliza. Ainda no parágrafo inicial, o orador pede ajuda e considera estar numa hora difícil.

No segundo parágrafo, M.F.S. introduz a justificativa do pedido: "eu troquei o amor verdadeiro por um amor que eu sei que não existe. Deixei o amor de minha mãe por um amor falso que ama outra pessoa". Nesse momento, um misto de paixões se imbrica: a vergonha pelo feito, o amor não correspondido e a certeza de que o amor verdadeiro é o de mãe. E num momento de desabafo e intimidade, o orador relata o seu desejo: "queria que umas páginas da minha vida voltace ao passado". Assim, o apelo aos sentimentos expressos no texto possibilita a comoção por parte do interlocutor por meio de emoções que incitam arrependimento, angústia e dor.

Ademais, no intuito de sensibilizar o auditório, o orador afirma ter a certeza de que não é possível voltar ao passado. A tristeza revelada pelo orador se faz presente em toda a carta que, embora em tamanho reduzido, retrata sofrimento e arrependimento de atitudes tomadas, causando, possivelmente, no auditório, um desejo de reverter a situação e resolver o problema que o aflige.

No último parágrafo, o orador realiza seu pedido, pois até então era só um desabafo, uma descrição do que justificaria o seu desejo e, possivelmente, revela o desejo de despertar no padre a necessidade de consolar aquele coração tão sofrido. Na 
súplica "faça com que esta pessoa goste um pouco de mim", o advérbio de intensidade mais uma vez se faz presente na expressão patêmica e revela força argumentativa, pois o orador implora por "um pouco" de amor. E continua: "Mim abençõe meu padrinho e minha família", estendendo o pedido de súplica também para a sua família. 0 locutor realiza escolhas lexicais que exprimem apelo emocional à sensibilidade do leitor. Pronuncia "meu padrinho" em vários momentos na carta com o objetivo de que Padre Cícero a escute e que a ajude a resolver aquela situação. Percebemos nas palavras expressas pelo orador a ideia de que ela não considera o Padre Cícero apenas como um ser que pode ajudá-la, mas, também, como um amigo a quem ela pode confessar as suas angústias.

Nesse sentido, a representação do "Padim" como amigo permite o desabafo materializado na carta e ao analisarmos o pedido, inferimos que ele suscita piedade no interlocutor. É uma tentativa de sensibilizar o auditório a aderir à tese de que, por não ser merecedora do amor do homem escolhido e por não poder voltar e realizar escolhas diferentes, o orador suplica pelo menos um mínimo de amor dedicado a quem sofre.

Dando continuidade, apresentamos a análise da carta de número 4 .

\section{Carta 4}

Ô meu Padre Cícero eu lhe pesso que mim ajude iajude meu Filho Ô meu Padre Cícero quem estar lhe pedindo e uma pobri mãe sofredora que já sofreu de mais e contínua sofrendo eu lhe pesso e lhe em ploro que me ajude é ajude $u$ meu filho pesso que faça dele um homem onesto e trabalhador tire Ele desta via de malandragem tenha misericordia dele faça com quer ele mude seja um bom homem e que a faste ele das maus companhia em nome do Pai do Filho é do Espirito Santo Amem.
Ô meu Padre Cícero rogai por noís

Ô meu Padre Cícero o nome dele é C.M.S. e o meu E. M.S.

A carta começa com um apelo evidente e textualizado em que o orador utiliza uma interjeição para evocar o Padre Cícero e já nesse momento há uma expressão que revela dor, sofrimento e angústia. 0 enunciado "Ô meu Padre Cícero" revela muito mais significativos que um vocativo que, normalmente, apresenta o gênero carta, pois nele está refletido um pedido de misericórdia que se confirma no pedido que se segue. A súplica é realizada por uma mãe: "quem está lhe pedindo é uma pobre mãe sofredora que já sofreu demais e continua sofrendo". O apelo se manifesta revestido de um sofrimento contínuo que, possivelmente, evoca no interlocutor o desejo de conceder a paz àquela mãe, e que só se concretizaria com o atendimento do seu pedido.

A carta não é dividida por parágrafos, o texto é contínuo, assim como os dizeres que compõem o teor do texto. 0 desejo de que o filho se torne um homem honesto e que as más companhias sejam afastadas resumem o pedido de graça e todo o restante da carta se constitui em expressões de súplicas. A expressão "Ô meu Padre Cícero" é textualizado outras vezes no texto, o que nos remete à ideia de agonia e aflição, uma vez que essa construção parece ser utilizada em um momento de grande desespero.

Embora seja uma carta bem pequena, com poucos dizeres e sem a preocupação com as características que o gênero exige, a carta apresenta uma forte carga emotiva revelada pelo orador. Inicialmente, recorre a expressões que enfatizam as sensações de angústia; em seguida, considera que quem sofre é uma mãe; depois, as repetições aflitas e, por último, uma situação que aparen- 
temente sugere desespero. A mãe insiste em dizer o nome do filho e o seu, a fim de garantir que não haja confusão na hora de atender ao pedido.

No decorrer do texto, a autora recorre aos verbos que demonstram a angústia que ela está sentindo naquele momento e o seu desejo pela escuta da sua prece: "pesso", "ajude", "faça", "sofreu". O verbo pedir é manifestado em alguns momentos no decorrer da carta. Esta escolha lexical evidencia a necessidade de ajuda que a mãe está precisando naquela ocasião. 0 verbo ajudar também se manifesta no texto "eu lhe pesso que mim ajude e ajude meu filho". Nessa construção, o produtor da carta declara que tanto ela quanto o seu filho necessitam da ajuda do padre. A maneira como as palavras são mobilizadas no texto para realizar o pedido demonstra humildade e bastante sofrimento por parte da solicitante. É notório que o manejo do léxico acionado na construção dessa carta atende, a nosso ver, ao propósito comunicativo do orador - obter resposta a sua súplica.

Há nessa carta uma encenação dramatizante de produção de sensibilidade por meio da importância do ser mãe. Para o orador, o fato de ser mãe pode despertar no interlocutor o desejo de que as mães não devem sofrer, mas que sofrem e, por isso, são as pessoas mais indicadas para terem seus pedidos atendidos.

A seguir, apresentamos as observações sobre a quinta carta.

\section{Carta 5}

Siupé 27.07.2001

Meu glorioso Padre Cicero vos sabe das minhas nescissidade peço lhe pelo o seu divino puder que der minha sauda para mim enfrentar a minha vida mim ajude eu pagar minhas contas ajude-me a minha vida finacera quem pegar este Bilhete reze pra mim meu nome e M. J. tenho 58 anos moro em Siupé São Gonçalo do amarante não tenho marido não tenho filho cuido de 3 sobrinho meu padre Cicero me ajude daqui para. o fim de agosto.

assina M. J.

No vocativo desta carta, o orador enaltece o padre por meio do adjetivo "glorioso" e nessa direção constrói seu posicionamento afirmando que o santo sabe das suas necessidades, menciona o que precisa, pede saúde para si mesmo e para a família e reafirma a necessidade de ajuda para pagar as contas.

A escolha lexical do adjetivo "glorioso" pela autora eleva e enaltece a figura do padre. Ao dizer "Meu glorioso padre Cicero", faz uso do pronome possessivo dando a ideia de que o religioso já faz parte da vida dela, e que ele é poderoso e grande para atender ao pedido realizado por ela e por muitas pessoas que necessitam das suas bênçãos.

Na despedida, que não foi separada do corpo do texto, o orador se apresenta com nome e idade, e com a descrição de "não tenho marido, não tenho filho, cuido de 3 sobrinhos, meu padre Cícero, me ajude daqui para o fim de agosto". Com isso, pede oração a quem por algum motivo tenha acesso à carta. As expressões acionadas no texto suscitam piedade, sugerem que o interlocutor se sensibilize da situação da oradora ao compadecer-se do cenário e atenda ao pedido. A produtora da carta direciona o pedido também a outros, que porventura tenham contato com a história e o pedido feito por ela.

0 desespero do orador é materializado no texto ao nos depararmos com o prazo estipulado para o atendimento da graça. Possivelmente, o problema financeiro se acentuaria no período descrito. A carta é pequena, 
contudo, as escolhas dos itens lexicais revelam uma fé inabalável e a impressão que se tem é a de que o santo é um personagem visível e que, de fato, pode resolver aquela situação, sobretudo, a financeira, e no tempo determinado no pedido.

O texto revela uma situação de desesperança vivida pelo orador, ao mesmo tempo em que mobiliza o sentimento de esperança, de compaixão e de benevolência do Padre Cícero em favor da solução do problema. Vale salientar que a compaixão é um sentimento que em sua constituição já inibe o que ocasionou o problema, não dando espaço a críticas sobre o que gerou a dificuldade financeira.

\section{Considerações finais}

Após a análise das cartas de romeiros, inferimos que os produtores mobilizam emoções (pathos) no discurso (logos) a partir do ethos revelado pelo orador, estando, portanto, esses três princípios (ethos, logos e pathos) articulados na empreitada persuasiva a que se propõem os textos. As emoções inscritas no discurso, externadas pelas imagens construídas nas cartas dos devotos do Padre Cícero, sejam elas de desespero da mãe que implora a libertação do filho em relação ao vício ou a outros perigos dessa natureza, sejam de apelo à proteção da família, à (re)conquista de um amor ou ao pagamento das dívidas, entre outras, revelam de todo modo que o ato de argumentar configura-se em uma estratégia que pretende provocar a sensibilidade do auditório.

O orador, ao expressar sua própria vivência (sofrimento, angústia, desespero, medo, piedade, tristeza, amor, fé, devoção etc.), faz com propriedade porque conhece como ninguém os fatos sobre os quais fala. Isso permite que ele utilize os argumentos de que necessita com maestria, pois os domina mais que qualquer outro ser, ora se aproximando, ora se distanciando do auditório, representado pela figura do Padre Cícero, que irá (ou não) agir de acordo com a emoção suscitada na carta.

Nessa construção argumentativa, a imagem do locutor (ethos), que se configura, a nosso ver, como um dos principais componentes, alcança essa dimensão valorativa graças aos aspectos interacionais envoltos nesses contextos enunciativos, que incluem a esfera cotidiana e familiar como mediadora e reguladora na construção dos argumentos, adicionando, ainda, as vivências desses sujeitos e os lugares que eles ocupam na sociedade, com todos os seus problemas e desafios.

As expressões que provocam efeitos patêmicos e são identificadas nas cartas de romeiros caracterizam-se por suscitarem paixões diversas e estão materializadas por meio de recursos linguísticos vários, como advérbios de intensidade (muito partido; muito difícil; goste um pouco), pronome possessivo (meu padrinho; minha vida); substantivos (padrinho, milagre, perdição, coração, fé, esperança, saúde, paz, alegria, felicidade, coração, misericórdia, saúde, vida); verbos imperativos (ilumine, proteja, abençoe, guarde, livre, afaste, ajude), entre outros. Essas unidades podem ser identificadas explicitamente na materialidade textual, mas os elementos culturais e sociais presentes na vida dos locutores também interferem diretamente nessas escolhas e na argumentatividade que apresentam nas cartas.

As pressuposições que lançamos no início deste trabalho se confirmaram, em certa medida, no tocante aos recursos linguísticos utilizados principalmente no início das cartas, onde estão presentes a saudação e a motivação para a escrita, e na parte final, na 
despedida. Conforme pudemos observar, esses elementos apresentam uma força argumentativa evidenciada na mobilização das emoções, que também se justificam pelos contextos interacionais, sociais e dialógicos que constituem as cartas de romeiros.

\section{Referências}

AMOSSY, R. A argumentação no Discurso. Tradução (coord.): Eduardo Lopes Pires e Moises Olímpio Ferreira. São Paulo: Contexto, 2018.

ARISTÓTELES. Retórica das paixões. Trad. do grego Isis Borges B. da FONSECA. Prefácio de Michel MEYER. São Paulo: Martins Fontes, 2000.

ARISTÓTELES. Retórica. Trad. de Manuel Alexandre Júnior, Paulo Farmhouse Alberto e Abel do Nascimento Pena, Lisboa: Imprensa Nacional

- Casa da Moeda, 2005 (Biblioteca de Autores Clássicos).

BAKHTIN, M. Os gêneros do discurso. Tradução de Paulo Bezerra. São Paulo: Editora 34, 2016.

BRAGA, A. M. C. Padre Cícero: sociologia de um padre, antropologia de um santo. 2007. 419f. Tese (Doutorado em Antropologia Social), PósGraduação em Antropologia Social, Universidade Federal do Rio Grande do Sul, Porto Alegre, 2007.

BRANCO, N. M. O dialogismo e a construção de sentido nas cartas encíclicas do Papa Bento XVI. 2012. 170f. Dissertação (Mestrado em Linguística), Pós-Graduação em Linguística, Universidade Federal de São Carlos, São Carlos, 2012.
FIORIN, J. L. Argumentação. 1. ed. São Paulo: Contexto, 2018.

NASCIMENTO, J. A relação entre lógica, páthos e éthos na Arte Retórica de Aristóteles. Anais de Filosofia Clássica, Rio de Janeiro, v. 9, n. 17, p. 38-60, 2015. ISSN 1982-5323 Disponível em: https://revistas.ufrj.br/index.php/FilosofiaClassica/article/view/1431/2689. Acesso em 25 ago. 2020.

NASCIMENTO, R. L. 0 gênero carta de romeiros escrita pelos devotos do Padre Cícero: da estrutura e do uso à conceituação. 2018. 238f. Tese (Doutorado em Linguística Aplicada), Programa de Pós-Graduação em Linguística, Universidade Federal do Ceará, Fortaleza, 2018.

RAMOS, F. R. L. Papel Passado - Cartas entre os devotos e o Padre Cícero. Fortaleza: Instituto Frei Tito de Alencar, 2011.

RODRIGUES-ALVES, M.S.; RADI, A.R. Uma conexão cósmica passional: o desastre pensado por Pasternak. In: FIGUEIREDO, M. F.; FERREIRA, F. A.; RODRIGUES-ALVES, M. S. (org.) 0 animal que nos habita: a retórica das paixões em $R e$ latos Selvagens. Vários autores. Franca, SP: Unifran, 2016. $208 \mathrm{p}$.

ROJO, R. Gêneros do discurso e gêneros textuais: questões teóricas e aplicadas. In: MEURER, J. L.; BONINI, A.; MOTA-ROTH, D. (org.). Gêneros: teorias, métodos, debates. São Paulo: Parábola Editorial, 2005. p. 184-207.

VOLÓCHINOV, V. Marxismo e filosofia da linguagem. Trad. Sheila Grillo e Ekaterina Vólkova Américo. 1. ed. São Paulo: Editora 34, 2017.

Recebido em: 12/03/2021

Aprovado em: 10/07/2021 